Palavras chave: Conservação ex-situ Secagem

Ortodoxa Recalcitrante

Histórico: Recebido 20/08/2015 Aceito 03/03/2016

Keywords: Ex-situ conservation Desiccation Orthodox Recalcitrant

Correspondência: rafamka@hotmail.com
Rafaella Carvalho Mayrinck', Tatiana Arantes Afonso Vaz', Antonio Claudio Davide'

\section{CLASSIFICAÇÃO FISIOLÓGICA DE SEMENTES FLORESTAIS QUANTO À TOLERÂNCIA À DESSECAÇÃO E AO COMPORTAMENTO NO ARMAZENAMENTO}

RESUMO: Este trabalho teve por objetivo classificar sementes de espécies florestais nativas da bacia do Alto Rio Grande quanto à tolerância à dessecação e ao comportamento no armazenamento. Testes de germinação e de umidade foram feitos para cada espécie: com as sementes recém-beneficiadas, imediatamente ao atingir $12 \%$ e $5 \%$ de umidade, e após três meses de armazenamento a $-18^{\circ} \mathrm{C}$, apenas para sementes com $5 \%$ de umidade. Com base nos testes de germinação e umidade, as sementes foram classificadas em recalcitrantes, intermediarias e ortodoxas. As sementes de Brosimum gaudichaudii, Erythroxylum deciduum, Eugenia pleurantha, Myrcia venulosa, Nectandra megapotamica foram classificadas como recalcitrantes ( $22.7 \%$ das espécies). Foram classificadas como intermediárias as sementes de Aegiphila sellowiana, Aspidosperma parvifolium, Blepharocalyx salicifolius, Casearia lasiophylla, Cassia occidentalis, Dalbergia miscolobium, Diospyros brasiliensis, Diospyros hispida, Ilex brevicuspis, Ilex cerasifolia, Myrocarpus fastigiatus, Senna aversiflora e Senna splendida (59.1\% das espécies). Miconia albicans, Platycyamus regnellii, Styrax camporum e Piptadenia gonoacantha foram classificadas como ortodoxas (18.2\% das espécies).

\section{PHYSIOLOGICAL CLASSIFICATION OF FOREST SEEDS REGARDING THE DESICCATION TOLERANCE AND STORAGE BEHAVIOUR}

ABSTRACT: This work aims to classify forest seeds native to the Alto Rio Grande region regarding the desiccation tolerance and storage behaviour. Germination and water content tests were performed in seeds of different species. The tests were conducted immediately after seed processing, at $12 \%$ and $5 \%$ of water content, and at $5 \%$ after 3 months of storage in $-18^{\circ} \mathrm{C}$. Based on the results obtained, seeds were classified into recalcitrant, intermediate and orthodox class. Seeds of Brosimum gaudichaudii, Erythroxylum deciduum, Eugenia pleurantha, Myrcia venulosa, Nectandra megapotamica were classified as recalcitrant (22.7\% of all species). Seeds of Aegiphila sellowiana, Aspidosperma parvifolium, Blepharocalyx salicifolius, Casearia lasiophylla, Cassia occidentalis, Dalbergia miscolobium, Diospyros brasiliensis, Diospyros hispida, llex brevicuspis, Ilex cerasifolia, Myrocarpus fastigiatus, Senna aversiflora, Senna splendida e Blepharocalyx salicifolius were classified as intermediate (59.1\% of all species). Seeds of Miconia albicans, Platycyamus regnellii, Styrax camporum and Piptadenia gonoacantha were classified as orthodox (I8.2\% of all species). 


\section{INTRODUCTION}

Physiological classification regarding seed desiccation tolerance and storage behaviour is imperative to ex situ conservation since the knowledge of the water content and environmental temperature of storage are essential for seed viability maintenance (HONG;ELLIS, 1996). According to their ability to survive different water contents and storage temperature seeds are classified into recalcitrant orthodox (ROBERTS, 1973) and intermediate (ELLIS et al., 1990) classes.

Recalcitrant seeds are not able to tolerate water removal, losing its viability when reaching 12$31 \%$ of water content (Roberts, 1973). These seeds show intense metabolism during its developing and post harvesting stages (BARBEDO; MARCOS FILHO, 1998; CASTRO et al., 2004), and normally have large seeds and fruits that prevents them from dying by desiccation (FARNSWORTH, 2000; PRITCHARD et al., 2004; HONG; ELLIS, 1998). On the other hand, orthodox seeds can be dried to low moisture contents (2-5\%) under diverse conditions without structural damage (Roberts, 1973); the ideal storage conditions are at or under $-18^{\circ} \mathrm{C}$. The longevity of these seeds increases with the decrease of temperature and relative humidity during storage, in a quantifiable and predictable way (HONG; ELLIS, 1996). Seeds with intermediate behaviour are those not included either in the orthodox or recalcitrant class (ELLIS et al., 1990; EIRA, 1996). Intermediate seeds are sensible to sub zero temperatures and tolerate partial desiccation (ELLIS et al., 1990).

The Alto Rio Grande region is very important for Brazil in economic and ecological terms. It covers 64 municipalities and an area of 15 thousand squared kilometers (SILVA et al. 2005). The main forest formations found in the region are semideciduous forests (VAN DEN BERG; OLIVEIRA-FILHO, 2000; SOUZA et al., 2003) and the main treats for the vegetation are agriculture (VAN DEN BERG; OLIVEIRA-FILHO, 2000), livestock and the expansion of the urban areas.

According to Tweddle et al. (2003), semi deciduous forests have about $75.0 \%$ of species producing orthodox seeds, $4.4 \%$ producing intermediate seeds and $20.6 \%$ producing recalcitrant seeds. So, due to the lack of information about seed behaviour regarding its desiccation tolerance and storage in the Alto Rio Grande region, the aim of this study was to classify the seed behaviour of 22 forest species native to forest fragments of the Alto Rio Grande region.

\section{MATERIAL AND METHODS}

\section{Fruit collection and processing}

The fruits were collected from January 20II to December 2012 in forest fragments of the Alto Rio Grande region, Lavras municipality, Minas Gerais, Brazil [(21 ${ }^{\circ} 14^{\prime} 30^{\prime \prime} S$ and $45^{\circ} 00^{\prime} 10^{\prime \prime} \mathrm{W}$ and $919 \mathrm{~m}$ a. s. I. (BRASIL, 1992)]. According to Köppen's climatic classification, the regional weather is Cwa with attributes of Cwb, presenting two well-defined seasons: dry, from April to September, and rainy, from October to March (KÖPPEN, 1936). The region is characterized as a transition between Mata Atlântica and Cerrado vegetation, with a predominance of a semi deciduous seasonal rainforests (VAN DEN BERG; OLIVEIRA-FILHO, 2000).

Observing such traits as color change, texture and early dehiscence, mature fruits were collected and transported to the laboratory immediately after collection. Processing was made manually, without sun exposition and following recommendations found in Davide et al. (1995).

\section{Determination of seed water content}

Shortly after processing, seeds were bottled, dried with paper towels and the water content was determined using four replicates varying from 0.5 to 6 grams of seeds, depending on the species, using the oven method at $103^{\circ} \mathrm{C}$ for 17 hours. To help the water loss process, species with large seeds were cut into small parts. The results were expressed as percentage of the fresh weigh (ISTA, 2004).

\section{Drying curve and storage}

Seeds were submitted to artificial drying using silica gel placed in boxes of the type "higrostat" (5 kg) with forced ventilation or boxes of the type "gerbox" (90 g) for small-sized seeds (up to $1 \mathrm{~cm}$ in major axis), with an equilibrium of the relative humidity around $5 \%$, and placed in a acclimatized room at $20^{\circ} \mathrm{C}$. Silica gel was replaced as soon as it showed color changes. Seed water content was monitored daily using the target weights to $12 \%$ and $5 \%$ of moisture content, determined by the Cromarty et al. (1982) equation.

Fresh seeds and those at 12 and 5\% of water content were submitted to water content (described above) and germination tests. Seeds at $5 \%$ of water content were divided in two smaller samples, one of these samples was taken immediately to germination test and the other sample to storage at $-18{ }^{\circ} \mathrm{C}$ for three months, undergoing water content and germination tests after that. 
For the germination test four replicates of 25 seeds each were used, incubated in a germination chamber (Magelsdorfi) at $25{ }^{\circ} \mathrm{C}$ and constant light, following the instructions of Brancalion et al. (2010), that recommended $25^{\circ} \mathrm{C}$ for germination tests of Brazilian tree species native to Cerrado and Atlantic Forest. Autoclaved sand was used as substrate, which was premoistened and autoclaved, and placed in plastic trays for large seeds, or three pre-moistened paper sheets in petri dishes for small-sized seeds (up to $\mathrm{I} \mathrm{cm}$ in the major axis). All the samples were kept moistened during the test period and the germination tests were conducted until all the seeds germinated or died (rotted).

\section{Seed classification}

The methodology proposed by Hong and Ellis (1996) was used to classify the seeds into one of three classes of seed behaviour, described shortly in the Figure I.

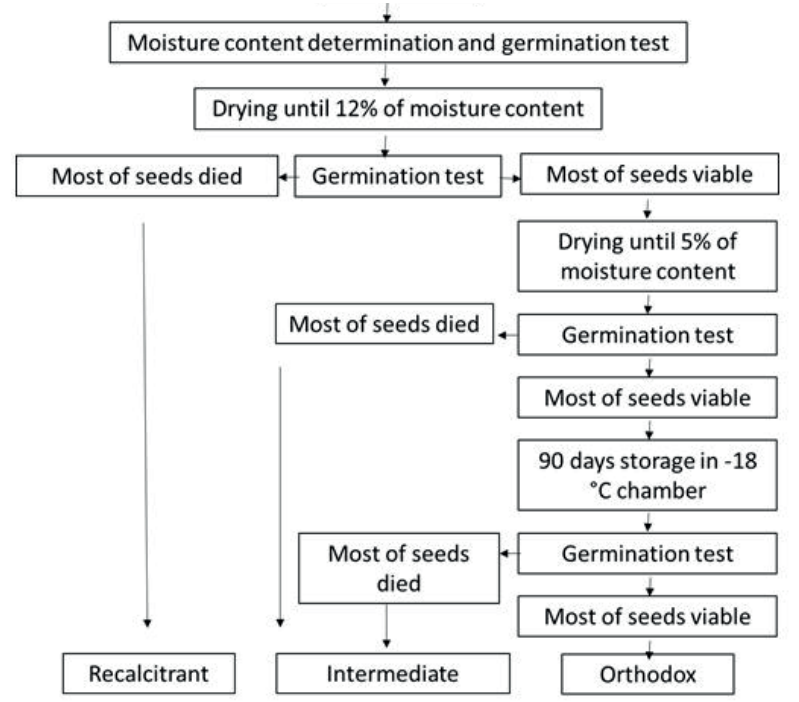

FIGURE 1 Simplified protocol for seed storage behaviour determination adapted from Hong and Ellis (1996).

FIGURA 1 Protocolo simplificado para classificação de sementes de acordo com o comportamento no armazenamento adaptado de Hong e Ellis (1996).

\section{Statistical Analysis}

All All the data were submitted to normality test (Shapiro Wilk). Normally distributed data were submitted to an analysis of variance (ANOVA) followed by a Tukey test to compare the means of germination in each point of drying (fresh, $12 \%, 5 \%$, and $5 \%$ of water content + storage). Non-normally distributed data were submitted to Kruskal Wallis analysis followed by Tukey test. All the tests were conducted using $5 \%$ probability.

\section{RESULTS AND DISCUSSION}

Among all species studied, $22.7 \%$ were classified as recalcitrant (Brosimum gaudichaudii, Erythroxylum deciduum, Eugenia pleurantha, Myrcia venulosa and Nectandra megapotamica); 59.1\% were classified as intermediate (Aegiphila sellowiana, Aspidosperma parvifolium, Casearia lasiophylla, Cassia occidentalis, Dalbergia miscolobium, Diospyros brasiliensis, Diospyros hispida, Ilex brevicuspis, Ilex cerasifolia, Myrocarpus fastigiatus, Senna aversiflora, Senna splendida and Blepharocalyx salicifolius); and 18.2\% were classified as orthodox (Miconia albicans, Platycyamus regnellii, Styrax camporum and Piptadenia gonoacantha) (Table I). Theseis percentages did not agree with those found by Tweddle et al. (2003), for semideciduos forest species.

No previous studies about seed storage behavior for Aegiphila sellowiana, Myrocarpus fastiggiatus and Myrcia venulosa seeds were found. Aegiphila sellowiana and Myrocarpus fastiggiatus were classified as intermediate while Myrcia venulosa was recalcitrant. Similarly, Aspidosperma parvifolium was classified as intermediate. However, Carvalho et al. (2006) classified others Aspidosperma species (Aspidosperma cylindrocarpon and Aspidosperma polyneuron) as orthodox. Piptadenia gonoacantha was classified as orthodox in the present study but Carvalho (2004) found recalcitrant behaviour for these seeds. Blepharocalyx salicifolius was classified as intermediate in this study and Rego (2012) classified it as recalcitrant.

Nectandra megapotamica was classified as recalcitrant. Similarly, Carvalho et al (2008) classified 3 other Nectandra species (Nectandra lanceolata, Nectandra oppositifolia and Nectandra grandiflora) as recalcitrant as well. Dalbergia miscolobium showed intermediate behaviour. According to Nogueira et al (2010), other Dalbergia species show medium germination at $10 \%$ of moisture, which makes sense for intermediate species.

Erythroxylum deciduum was classified as recalcitrant. Similarly, Da Silva et al (2014) classified Erythroxylum squamatum as recalcitrant. In previous studies, Wetzel (1997) and Carvalho (2000) classified Brosimum gaudichaudii and Eugenia pleurantha as recalcitrant, the same classication found in this study. Diospyro hispida was classified as intermediate in this study and also by Salomão et al (1997). Diospyro brasiliense, which belongs to the same genus of Diospyro hispida was classified as intermediate as well. Platycyamus regnelli was considered orthodox in the present study, likewise by Salomão et al., (1997). Seeds of Casearia lasiophylla were classified as intermediate in this work, 
however, Carvalho et al. (2006) could not classify this species in their work due to the presence of dormancy (hard tegument, possible physical dormancy), which can explain why the germination of these seeds was low in the present work. Probably, if dormancy breaking treatments were applied, the germination percentages may differ from the values found in the present study.

Fresh seeds of Illex brevicuspis had $80 \%$ germination and at $5 \%$ of moisture content the germination dropped to $59 \%$. When subjected to 3 months storage in $-18^{\circ} \mathrm{C}$, the germination was $31 \%$, thus, Illex brevicuspis was classified as intermediate. Ilex cerasifolia followed a similar pattern, with initial germination of $91 \%$, at $5 \%$ water content germination was $72 \%$ and after 3 months of storage germination was only $5 \%$, being also classified as intermediate. Fresh seeds of Miconia albicans had
$90 \%$ germination and $77 \%$ germination after 3 months storage at $-18^{\circ} \mathrm{C}$, being safely classified as orthodox.

Fresh seeds of Styrax camporum presented low germination percentage, however, presented $82 \%$ of germination after 3 months storage at $-18^{\circ} \mathrm{C}$, hence, the specie was classified as orthodox. According to Kermode and Bewley (1985), mature fresh seeds of Ricinus communis presented $30 \%$ of normal seedlings, but using seeds after drying and rehydration, the germination test presented $100 \%$ of normal seedlings. The authors state that drying process collaborates to finish the developing process and stimulate germination in orthodox seeds. Seeds of S. camporum also could present some kind of dormancy overcoming by storage in low temperature as happens with other seeds as related by Souza et al.

TABLE 1 Classification of forest seeds collected at Alto Rio Grande basin, at Lavras region, MG, regarding its desiccation tolerance and storage behaviour.

TABELA 1 Classificação de sementes de espécies florestais coletadas na bacia do Alto Rio Grande, na região de Lavras, MG, em relação a tolerância a dessecação e comportamento no armazenamento.

\begin{tabular}{|c|c|c|c|c|c|c|c|}
\hline Species & $P$ value & $\mathrm{DMC}$ & $\mathrm{GI}$ & G12 & G5 & G-18 & Classification \\
\hline Aegiphila sellowiana & 0.004 & 30.5 & $100 a$ & $100 a$ & $94 a$ & $57 b$ & Intermediate \\
\hline Aspidosperma parvifolium & 0.010 & 22.4 & $82 a$ & $71 a$ & $75 a$ & $11 b$ & Intermediate \\
\hline Blepharocalyx salicifolius & 0.002 & 50.4 & $89 a$ & $88 b$ & $60 \mathrm{~b}$ & $60 b$ & Intermediate* \\
\hline Brosimum gaudichaudii & 0.002 & 62.0 & $67 a$ & $\mathrm{Ob}$ & $\mathrm{Ob}$ & $0 b$ & Recalcitrant \\
\hline Casearia lasiophylla & 0.016 & 50.6 & $92 a$ & $20 b$ & $18 \mathrm{~b}$ & $13 b$ & Intermediate* \\
\hline Cassia occidentalis & 0.006 & 13.2 & $82 a$ & $82 a$ & $27 \mathrm{~b}$ & $15 b$ & Intermediate \\
\hline Dalbergia miscolobium & 0.008 & 15.9 & $100 a$ & $90 a b$ & $90 a b$ & $57.5 b$ & Intermediate \\
\hline Diospyros brasiliensis & 0.012 & 43.3 & $67.5 a$ & $67.5 a$ & $60 a$ & $0 b$ & Intermediate \\
\hline Diospyros hispida & 0.003 & 49.5 & $86 a$ & $56 b$ & $63 b$ & $51 \mathrm{c}$ & Intermediate \\
\hline Erythroxylum deciduum & 0.002 & 53.9 & $94.4 a$ & $\mathrm{Ob}$ & $\mathrm{Ob}$ & $\mathrm{Ob}$ & Recalcitrant \\
\hline Eugenia pleurantha & 0.002 & 58.9 & $95 a$ & $3 b$ & $0 b$ & $\mathrm{Ob}$ & Recalcitrant \\
\hline Ilex brevicuspis & $<0.001$ & 12.2 & $90 a$ & $80 a$ & $59 b$ & $32 c$ & Intermediate \\
\hline Ilex cerasifolia & 0.008 & 16.0 & $91 a$ & $85 a$ & $72 b$ & $5 c$ & Intermediate \\
\hline Miconia albicans & $<0.001$ & 9.1 & $90 a$ & NP & $69 b$ & $77 \mathrm{~b}$ & Orthodox \\
\hline Myrcia venulosa & 0.002 & 60.1 & $96 a$ & $\mathrm{Ob}$ & $\mathrm{Ob}$ & $0 b$ & Recalcitrant \\
\hline Myrocarpus fastigiatus & 0.070 & 21.0 & $16 a$ & $16 a$ & $30 a$ & $9 a$ & Intermediate \\
\hline Nectandra megapotamica & 0.002 & 47.2 & $85 a$ & $\mathrm{Ob}$ & $0 b$ & $\mathrm{Ob}$ & Recalcitrant \\
\hline Piptadenia gonoacantha & 0.002 & 13.1 & $97 a$ & $72 b$ & $56 b$ & $67 b$ & Orthodox* \\
\hline Platycyamus regnellii & $<0.001$ & 14.4 & $85 b$ & $100 a$ & $100 a$ & $90 a$ & Orthodox \\
\hline Senna aversiflora & 0.094 & 18.0 & $26 a$ & $21 a$ & $21 a$ & $5.25 b$ & Intermediate* \\
\hline Senna splendida & 0.020 & 26.6 & $60 a$ & $66.2 a$ & $67.5 a$ & $0 b$ & Intermediate* \\
\hline Styrax camporum & $<0.001$ & 27.5 & $39 b$ & $49 b$ & $54 b$ & $82 a$ & Orthodox \\
\hline
\end{tabular}

NP: test not performed; DMC: Dispersal moisture content; IG: Initial germination; G12: Germination at 12\% of moisture content; G5: Germination at 5\% of moisture content; G-18: Germination at $5 \%$ of moisture content stored for 3 months at $-18{ }^{\circ} \mathrm{C}$. Means followed by the same letter do not differ among other means $(p>0.05)$. *result obtained differ from results found in literature.

NP: Não realizado; DMC: Umidade de dispersão; IG: Germinação inicial; G12: Germinação aos 12\% de umidade; G5: Germinação aos 12\% de umidade; G-18: Germinação aos $5 \%$ de umidade após 3 meses de armazenamento a $-18^{\circ} \mathrm{C}$. Médias seguidas por letras iguais não diferem entre si ( $p>0.05$ ). *resultados obtidos diferem daqueles encontrados na literatura. 
(2007) and Zaidan e Barbedo (2004). Further studies about its germination process should be conducted.

Seven of the all studied species belongs to Fabaceae family, of which five were classified as intermediate and two as orthodox. Seeds of Senna aversiflora and Senna splendida had low germination in all water contents tested, and were classified as intermediate. However, the low germination percentage can be attributed to a possible physical dormancy. Several papers have been reported physical dormancy in seeds of the Senna genus, for example, Senna macranthera (POZITANO e ROCHA, 20II), Senna Silvestris (MARANHO and PAIVA, 20I2), Senna multijuga (RODRIGUES-JUNIOR et al., 20I4), among others. Jayasuriya et al. (20I3) studying 100 Fabaceae species from Sri Lanka, found 94 presenting orthodox behaviour, of those 91 presented some kind of dormancy and 86 presented physical dormancy. Although there are exceptions, most of Fabaceae species produce dormant (DICKIE and PRITCHARD, 2004; SAUTU et al. 2006) and orthodox (CARVALHO et al., 2006; JAYASURIYA et al. 2013) seeds. Thus, a possible presence of physical dormancy could have led to a wrong classification in these species, and more studies are necessary to properly classify the behaviour of the Senna species of this study.

Two species from Aquifoliaceae and Ebenaceae family were studied in this work and all of them were classified as intermediate, however, Ellis et al. (1987) pointed out that Aquifoliaceaes species normally have orthodox seeds. Some studies show the drying rate influencing the desiccation tolerance of some species, as shown by Jose et al. (20II) and Magistralli et al. (20I5), who found greater desiccation tolerance in Magnolia ovata and Genipa americana, , respectively, when submitted to slow drying rather than fast drying. The drying rate of Aquifoliaceae seeds should be tested in further investigations. From three Myrtaceae species studied, two were classified as recalcitrant and one as intermediate. Carvalho et al (2006), studying seed storage behaviour, found two Myrtaceae species with recalcitrant behaviour.

Swaine and Whitmore (1988) proposed a forest species classification based on ecological classes, as pioneer and non-pioneer, which were divided in climax shade tolerant and climax light demanding. Pioneer species normally produce orthodox and dormant seeds (KAGEYAMA and VIANA, 199I) while non-pioneer species normally produce recalcitrant seeds (KAGEYAMA and VIANA, 199I; PAMMENTER and BERJAK, 2000). From all of recalcitrant species, three were pioneer and two non-pioneer. From intermediate species, there were six pioneer species and three non-pioneer species. Two intermediatte species were not classified by previous authors regarding its ecological classification. For orthodox species, there were three pioneer and one non-pioneer species. Jose et al. (2007), studying species from riparian forest in Minas Gerais, did not find the classical relationship among ecological groups and seed storage behaviour. They classified Metrodorea stipularis and Miconia argyrophylla as orthodox, which are climax species. Similarly, Carvalho et al. (2006), studying seed storage behaviour and its relation to ecological groups, found orthodox seeds in the pioneer, shade tolerant and climax light demanding groups.

The highest water content found in recalcitrant seeds was $62 \%$ (Brosimum gaudichaudii) and the minimum was $47.2 \%$, (Nectandra megapotamica). For orthodox seeds, the highest value found was $27.5 \%$ (Styrax camporum) and the lowest was $9.1 \%$ (Miconia albicans). The water content found in intermediate seeds was somewhere between the values of recalcitrant and orthodox seeds (Figure 2). Similarly, Hong and Ellis (1996) affirmed that eeds with moisture content lower than $25 \%$ tend to behave in an orthodox way. A variety of studies support the fact that recalcitrant seeds show higher moisture content than intermediate seeds, and intermediate seeds show higher water content than orthodox seeds (BERJAK and PAMMENTER, 1984; HONG and ELLIS, 1998; DAWS et al, 2006; HAMILTON et al., 2013).

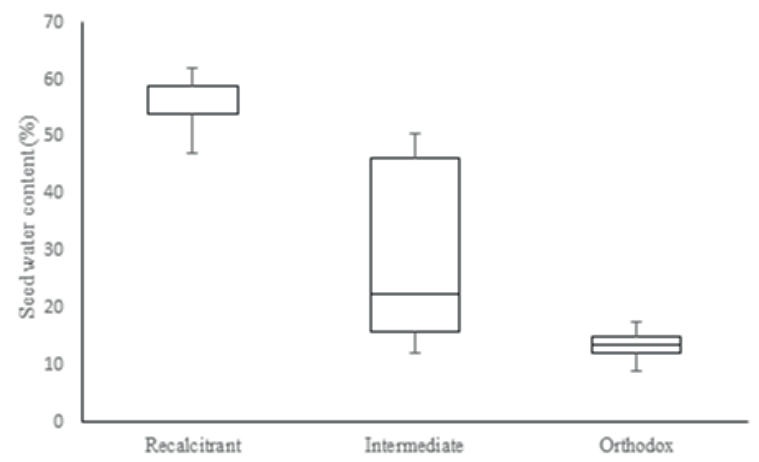

FIGURE 2 Box plot analysis of the dispersal water content of 22 seeds of species from the Alto Rio Grande region.

FIGURA 2 Análise de box plot do conteúdo de água de sementes durante a dispersão de 22 espécies da região do Alto Rio Grande.

\section{CONCLUSION}

In conclusion, seeds of Brosimum gaudichaudii, Erythroxylum deciduum, Eugenia pleurantha, Myrcia venulosa and Nectandra megapotamica were classified as recalcitrants, which is equivalent to $22.7 \%$ of the studied species. Seeds of Aegiphila sellowiana, 
Aspidosperma parvifolium, Blepharocalyx salicifolius, Casearia lasiophylla, Cassia occidentalis, Dalbergia miscolobium, Diospyros brasiliensis, Diospyros hispida, llex brevicuspis, Ilex cerasifolia, Myrocarpus fastigiatus, Senna aversiflora and Senna splendida were classified as intermediate, $59.1 \%$ of all the species. Seeds of Miconia albicans, Platycyamus regnellii, Styrax camporum and Piptadenia gonoacantha were classified as orthodox, which is equivalent of $18.2 \%$ of the studied species.

\section{REFERENCES}

BARBEDO, C. J.; MARCOS FILHO, J. Tolerância à dessecação em sementes. Acta Botanica Brasilica, Porto Alegre, v. I2, n. 2, p.145-164, 1998.

BERJAK, P.; DINI, M.; PAMMENTER, N. W. Possible mechanisms underlying the different dehydration responses in recalcitrant and orthodox seeds: desiccation-associated subcelular changes in propagules of Avicennia marina.Seed Sci. Technol, v. I2, p. 365-84, 1984.

BRANCALION, P. H. S., NOVEMBRE, D. L. C., RODRIGUES, R. R. Temperatura ótima de germinação de sementes de espécies arbóreas brasileiras. Revista Brasileira de Sementes, vol. 32, n 4 p. 015 - 021, 2010.

BRASIL. Ministério da Agricultura e da Reforma Agrária. Normais Climatológicas, Brasília, 196|-1990. Brasília: DNDV/CLV, 84 p, 1992.

CARVALHO, L. R., DAVIDE, A. C., DA SILVA, E. A. A., DE CARVALHO, M. L. M. Classificação de sementes de espécies florestais dos gêneros nectandra e ocotea (lauraceae) quanto ao comportamento no armazenamento. Revista Brasileira de Sementes, vol. 30, $n^{\circ}$ I, p. I-9, 2008.

CARVALHO, L. R.; DA SILVA, E. A. A.; DAVIDE, A. C. Classificação de sementes florestais quanto ao comportamento no armazenamento. Revista Brasileira de Sementes, v. 28, n. 2, p. I5-25, 2006.

CASTRO, R. D de; BRADFORD, K. J.; HILHORST, H. W. Desenvolvimento de sementes e conteúdo de água In: Germinaçao. Do básico ao aplicado. Artmed Editora, p. 5I-67, 2004.

CROMARTY, A. S., ELLIS, R. H., ROBERTS, E. W. The design of seed storage facilities for genetic conservation, IBPGR, 1982.

DA SILVA, B. M., OLIVEIRA, C., CESARINO, F., VIEIRA, R. $D$. Armazenamento e germinação de sementes de coca (Erythroxylum squamatum Sw.). Revista Trópica - Ciências Agrárias e Biológicas, p.39-47, v.08, n.0I, 2014

DAVIDE, A. C.; FARIA, J. M. R.; BOTELHO, S. A. Propagação de espécies florestais. Belo Horizonte: CEMIG/UFLA/ FAEPE, 1995.
DAWS, M. I.; GARWOOD, N. C.; PRITCHARD, H. W. Prediction of desiccation sensitivity in seeds of woody species: a probabilistic model based on two seed traits and 104 species. Annals of Botany, v. 97, n. 4, p. 667-674, 2006.

DICKIE, J. B.; PRITCHARD, H. W. Systematic and evolutionary aspects of desiccation tolerance in seeds. Desiccation and survival in plants: drying without dying. Wallingford, UK: CAB International, p. 239-259, 2002.

EIRA, M. T. S. Classificação de sementes orthodoxas, recalcitrantes ou intermediárias. Conservación de germoplasma vegetal. IIICA-PROCISUR. Diálogo. Montevideo, v. I, p. II9-I22, 1996.

ELLIS, R. H.; HONG, T. D.; ROBERTS, E. H. An intermediate category of seed storage behaviour? Journal of Experimental Botany, Oxford, v. 4I, n. 9, p. II67-II74, Sept. 1990.

ELLIS, R. H.; HONG, T. D.; ROBERTS, E. H. The development of desiccation-tolerance and maximum seed quality during seed maturation in six grain legumes. Annals of Botany, v. 59, n. I, p. 23-29, 1987.

FARNSWORTH, E. The ecology and physiology of viviparous and recalcitrant seeds. Annual Review of Ecology and Systematics, p. 107-138, 2000.

HAMILTON, K. N., OFFORD, C. A., CUNEO, P., DESEO, M. A comparative study of seed morphology in relation to desiccation tolerance and other physiological responses in 7I Eastern Australian rainforest species. Plant Species Biology. V. 28, p. 5I-62, 2013.

HONG, T. D.; ELLIS, R. H. Contrasting seed storage behaviour among different species of Meliaceae. Seed Science and Technology, v. 26, n. I, p. 77-95, 1998.

HONG, T.D.; ELLIS, R. H. A protocol to determine seed storage behaviour. Rome: International Plant Genetic Resources Institute, 1996. 55p. (Technical Bulletin, I).

INTERNATIONALSEED TESTING ASSOCIATION. International rules for seed testing. Switzerland: ISTA, 2004.

JAYASURIYA, K. M. G., ASANGA. S. T. B. WIJETUNGA, J. M., BASKIN, C. C. Seed dormancy and storage behaviour in tropical Fabaceae: a study of 100 species from Sri Lanka. Seed Science Research, v. 23, n. 04, p. 257-269, 2013.

JOSÉ, A. C.; SILVA, E; A. D; DAVIDE, A. C. Classificação fisiológica de sementes de cinco espécies arbóreas de mata ciliar quanto a tolerância à dessecação e ao armazenamento. Revista Brasileira de Sementes, v. 29, n. 2, p. I7I-I78, 2007.

JOSÉ,A. C., Da Silva, E.A.A.; Davide, A.C.; Melo, A.J.S.; Toorop, P.E. Effects of drying rate and and storage time on Magnolia ovata Spreeng. On seed viability. Seed Science and Technology, Volume 39, Number 2 
KAGEYAMA, P.Y.; VIANA, V.M. Tecnologia de sementes e grupos ecológicos de espécies arbóreas tropicais. In: SIMPÓSIO BRASILEIRO SOBRE TECNOLOGIA DE SEMENTES FLORESTAIS, 2., 1989, Atibaia, SP. Anais... Atibaia. Instituto Florestal, 1991. p.197-215

KERMODE, ALLISON R.; BEWLEY, J. DEREK. The Role of Maturation Drying in the Transition from Seed Development to Germination I. ACQUISITION OF DESICCATIONTOLERANCE AND GERMINABILITY DURING DEVELOPMENT OF Ricinus communis L. SEEDS. Journal of experimental botany, v. 36, n. 12, p. 1906-1915, 1985.

KÖPPEN, W. Das geographische system der klimate. In: KÖPPEN, W.; GEIGER, R. (Ed.). Handbuch der klimatologie. Berlin: Gebruder Borntraeger, 1936. v. I, p. I-44, part C.

MAGISTRALI, P. R., JOSE, A. C., FARIA, J. M. R., NASCIMENTO, J. F. Slow drying outperforms rapid drying in augmenting the desiccation tolerance of Genipa americana seeds. Seed science and technology. V. 43, n. I, 2015.

MARANHO, A. S., PAIVA, A. V. Crescimento inicial de mudas de Senna silvestris (vell.) h. s. irwin \& barneby cultivadas em diferentes substratos. REVSBAU, Piracicaba - SP, v.6, n.4, p. I-I4, 20II.

NOGUEIRA, F. C. B., MEDEIROS FILHO, F., GALÀO, M. I. Caracterização da germinação e morfologia de frutos, sementes e plântulas de Dalbergia cearensis Ducke (pauvioleta) - Fabaceae. Acta bot. bras. 24(4): 978-985. 2010.

PAMMENTER, N. W., BERJAK, P. A review of recalcitrant seed physiology in relation to desiccation-tolerance mechanisms. Seed Science Research, Wallingford, v.9, p. I3-37, 2000.

POZITANO, M. ROCHA, S. C. S. CARACTERIZAÇÃO FÍSICA E GERMINAÇÃO DE SEMENTES DE Senna macranthera. Revista Brasileira de Sementes . Vol. 33, Issue 4, p. 777-784. 20 I I.

PRITCHARD, H. W., DAWS, M. I., FLETCHER, B. J., GAMENE, C. S., MSANGA, H. P., OMONDI, W. Ecological correlates of seed desiccation tolerance in tropical African dryland trees. American Journal of Botany, v. 9I, n. 6, p. 863-870, 2004.

REGO, S. S. TOLERÂNCIA À DESIDRATAÇÃO E ARMAZENAMENTO DE SEMENTES DE Blepharocalyx salicifolius (Kunth) Berg. E Casearia decandra Jacq. Tese apresentada ao curso de Pós-graduação em Engenharia Florestal, Universidade Federal do Paraná. 2012.

ROBERTS, E. H. Predicting the storage life of seeds. Seed Science and Technology, Zurich, v. I, n. 3, p. 499-5I4, 1973.

RODRIGUES-JUNIOR, A. G., FARIA, J. M. R., VAZ, T. A. A. NAKAMURA, A. T., JOSÉ, A. C. Physical dormancy in Senna multijuga (Fabaceae: Caesalpinioideae) seeds: the role of seed structures in water uptake. Seed Science Research. V. 24. N. 2. 2014.
SALOMÃO, A. N.; EIRA, M. T. S.; CUNHA, R.; SANTOS, I. R. I.; MUNDIM, R. C.; REIS, R. B. Padrões de germinação e comportamento para fins de conservação de sementes de espécies autóctones: madeireiras, alimentícias, medicinais e ornamentais. Brasília, DF: EMBRAPA-CENARGEN, 1997. 12 p. (EMBRAPACENARGEN. Comunicado técnico, 23).

SAUTU, A. BASKIN, J. M., BASKIN, C. C., CONDIT, R. Studies on the seed biology of 100 native species of trees in a seasonal moist tropical forest, Panama, Central America. Forest Ecology and Management, v. 234, n. I, p. 245-263, 2006.

SILVA, A. M., OliVEIRA, P. M., MELO, C. R., PIERANGELI, C. Vazões mínimas e de referência para outorga na região do Alto Rio Grande, Minas Gerais. Revista Brasileira de Engenharia Agrícola e Ambiental v. 10, n.2, p.374-380, 2005

SOUZA I. L., J. R. P., TAKAHASHII, S. A., GUIRAUDII, A. E. Y. M. C., \& ROCHAlll, J. N. Tempo de armazenamento e temperatura na porcentagem e velocidade de germinação das sementes de camomila. Ciência Rural, v 37, n 4, 2007.

SOUZA, J. S., ESPIRITO-SANTO, F. D. B., FONTES, M. A. O., OLIVEIRA-FILHO, A. T., BOTEZELLI, L. Análise das variações florísticas e estruturais da comunidade arbórea de um fragmento de floresta semidecídua às margens do rio Capivari, Lavras-MG. R. Árvore, Viçosa-MG, v.27, n.2, p. I85-206, 2003.

SWAINE, M. D.; WHITMORE, T. C. On the definition of ecological species groups in tropical rain forests. Vegetatio, v. 75, n. I-2, p. $81-86,1988$.

TWEDDLE, J. C., DICKIE, J. B. BASKIN, C. C. BASKIN, J. M. Ecological aspects of seed desiccation sensitivity. Journal of ecology. Volume 9I, Issue 2. April 2003.

VANDENBERG, EDUARDO; OLIVEIRA-FILHO,A. T. Composição florística e estrutura fitossociológica de uma floresta ripária em Itutinga, MG, e comparação com outras áreas. Revista Brasileira de Botânica, v. 23, n. 3, p. 23I-253, 2000.

WETZEL, M. M. V. S. Época de dispersão e fisiologia de sementes do cerrado. 1997. 168p. Dissertação (Doutorado em Ecologia) - Universidade de Brasília, Brasília.

ZAIDAN, L.B.P.; BARBEDO, C.J. Quebra de dormência em sementes. In: FERREIRA, A.G.; BORGHETTI, F. (Orgs.) Germinação - do básico ao aplicado. Porto Alegre: Artmed, 2004. Cap. 8, p.|35-146. 
